\title{
REGIONAL INDUSTRIAL CHANGE, INDUSTRIAL RESTRUCTURING, AND U.S. INDUSTRIAL POLICY
}

Barry M. Moriarty*

\section{Introduction}

United States industrial policy over the years has emerged from attempts to sight on a moving target. At various times the policy has centered on restricting the penetration of imports from overseas competitors by setting tariffs and quotas; on enhancing investment in new capacity and equipment through tax allowances for accelerated depreciation; on encouraging research into new product development and process technology by investment tax credits; on promoting the expansion of overseas markets for exports through various forms of assistance; on maintaining market competition through anti-trust regulations that restrict monopoly formation; and on encouraging the location of manufacturing in backward, underprivileged or problem areas of the country by a variety of tax, grant and loan programs (Moriarty, 1980, chapters 4 and 13).

The target, many times, was brought into focus by special interest groups able to influence government to assist them with their problems. In recent years, the problems have stemmed from unprecedented unemployment, interest and inflation rates; balance of trade deficits; business failures; currency exchange fluctuations; product imports; infrastructure deterioration; interregional and intraregional population and employment redistribution; and the dominance of multinational enterprises in product and security markets and in acquisition and divestiture activities. The commonality of the various targets has been the pursuit of an industrial policy that would enhance the competitive stance of American business in both domestic and international market places. Industrial policy is, thus, a series of micro-economic policies designed to deal with specific problems that the nation's macro-economic policy has failed to resolve.

It is very unlikely that many domestic

*The University of North Carolina at Chapel Hill. This paper was the presidential address at the 25th annual meeting of the Southern Regional Science Association, New Orleans, 1986. economic policies useful for dealing with the problems of past decades will be useful in the future. In the past, the nation was a more closed economic system dominated by a large number of small-scale industrial enterprises. The internationalization of banking, telecommunications and industry has created a more open system in which large scale firms predominate: multi-facility, multinational enterprises capable of functionally restructuring their operations and making the necessary locational adjustments to accommodate the varying policies of individual nations. The varying national policies have led to the destabilizing of the international economic order. To restore stability will eventually require unprecedented international cooperation.

This paper briefly describes the location and investment trends of manufacturing over the past few decades and some of the factors responsible for the trends. It then discusses a set of proposals that should be rejected as national policy components and outlines one that aids in stabilizing manufacturing employment. The proposal is based upon the most fundamental theory underlying regional science: the influence that the cost of overcoming distance has on the location of economic activity.

\section{Regional Industrial Change}

Manufacturing production in the United States and many other industrialized nations has been undergoing a geographic redistribution at both interregional and intraregional scales for several decades (Cromley and Leinbach, 1981; Erickson, 1976a and 1976b; Erickson and Leinbach, 1979; Erickson and Wasylenko, 1980; Hansen, 1979; Moriarty, 1980, 1981, 1983, 1986; Norton and Rees, 1979; Park and Wheeler, 1983; Rees, 1979; Struyk and James, 1975; Till, 1973; Zelinsky, 1962). While manufacturing employment has been slowly increasing in this country, its percentage of the total workforce has been declining. Never greater than 30 percent of the work- 
Table 1

Changes in Manufacturing Employment by Type and Region: 1954-1982 (in thousands)

\begin{tabular}{|c|c|c|c|c|c|c|c|c|c|}
\hline Region & $\begin{array}{l}\text { Total } \\
\text { Employment } \\
\text { Change }\end{array}$ & $\begin{array}{c}\text { 1954-1967 } \\
\text { Production } \\
\text { Worker } \\
\text { Change }\end{array}$ & $\begin{array}{l}\text { Nonprod. } \\
\text { Worker } \\
\text { Change }\end{array}$ & $\begin{array}{c}\text { Total } \\
\text { Employment } \\
\text { Change }\end{array}$ & $\begin{array}{c}1967-1982 \\
\text { Production } \\
\text { Worker } \\
\text { Change }\end{array}$ & $\begin{array}{l}\text { Nonprod. } \\
\text { Worker } \\
\text { Change }\end{array}$ & $\begin{array}{c}\text { Total } \\
\text { Employment } \\
\text { Change }\end{array}$ & $\begin{array}{l}1954-198 \\
\text { Production } \\
\text { Worker } \\
\text { Change }\end{array}$ & $\begin{array}{c}\text { Nonprod. } \\
\text { Worker } \\
\text { Change }\end{array}$ \\
\hline Mfg. Belt & 741.9 & 30.9 & 711.0 & $-2,119.8$ & $-2,256.8$ & 136.0 & $-1,377.9$ & $-2,225.9$ & 847.0 \\
\hline $\begin{array}{l}\text { Other } \\
\text { United States }\end{array}$ & $2,445.1$ & $1,524.9$ & 920.2 & $1,918.0$ & 712.3 & $1,205.7$ & $4,363.1$ & $2,237.2$ & $2,125.8$ \\
\hline
\end{tabular}

The Manufacturing Belt includes the New England, Mid-Atlantic and East North-Central census regions.

Other United States includes the remaining six continental U.S. census regions.

Source: Compiled by author from U.S. Census of Manufacturers, 1954, 1967 and 1982.

force, manufacturing employment declined from 25 percent of total employment in 1950 to 22 percent in 1980 . Once highly concentrated in the Manufacturing Belt, manufacturing employment in each census region of the country had nearly reached parity with its share of the country's total population by 1980 .

During the period 1954-1982, total manufacturing employment in the country grew by nearly 3 million jobs (Table 1). The Manufacturing Belt experienced a net loss of 1.4 million workers (all of it between 1977-1982) while the rest of the country grew by nearly 4.4 million. In 1954, the Manufacturing Belt had 64 percent of the nation's manufacturing employment but only 47 percent in 1982 . The Manufacturing Belt and remainder of the continental United States were evenly divided in their share of manufacturing employment in the late 1970 s. For the country as a whole, virtually the entire net growth in employment was in nonproduction workers, mostly salaried workers engaged in management, supervision, sales, research and development, and other support activities. Only 11,300 net jobs were gained in wageeamers directly involved in production. Nonproduction workers accounted for 23 percent of manufacturing employment in 1954 but 35 percent in 1982.

A striking difference, however, occurred throughout the period in the growth of production and nonproduction workers between the two major regions of the country. While the Manufacturing Belt registered a net total employment loss of nearly 1.4 million workers, the loss represented a decline of more than 2.2 million production jobs but a gain of 847,000 nonproduction jobs. Until the 1981-1982 recession, the Manufacturing Belt for some time had been offsetting losses in production workers by more than compensatory gains in nonproduction workers. The nearly 4.4 million worker increase realized by the rest of the country over the 1954-1982 period was nearly evenly divided between production workers and nonproduction workers. But a higher percentage of manufacturing workers in the Manufacturing Belt were engaged in nonproduction jobs than in the rest of the country (37 percent compared to 33 percent). Considering that manufacturing still comprised a higher percentage of the total workforce in the Manufacturing Belt (27 percent in 1980) than in the rest of the country (19 percent), nonproduction workers tended to be heavily concentrated there. Research also has revealed the near total substitution of durable goods employment for nondurable goods employment in the Northeast between 1950 and 1970 (Howell, 1975).

Not only has the redistribution of manufacturing occurred between regions of the country, but it has occurred within regions as well. The average percentage of the total labor force residing in nonmetropolitan areas employed in manufacturing has been increasing for some time-from an average of 13.7 percent in 1950 to more than 24 percent in 1980 (Heaton and Fuguitt, 1979; Fuguitt and Beale, 1984). Between 1950 and 1970, the proportion of the labor force working in industrial sectors characterized by low wage rates (food processing, textiles, apparel and furniture) increased from 7.8 percent to 9.1 percent, while the proportion working in sectors paying above average rates for the nation as a whole nearly doubled (from 5.9 percent to 11.5 percent). The 1960s saw manufacturing employment in- 
crease by 4.4 percent in metropolitan areas of the country whereas nonmetropolitan counties increased by 23.8 percent. The 1970 s revealed metropolitan areas increased by 7.3 percent and nonmetropolitan counties by 20.3 percent.

The data reveal that manufacturing employment in the country has a strong distancedecay from the Manufacturing Belt, where nonproduction workers have become concentrated, while at the same time production workers have become more dispersed throughout other regions of the country. Evidence also exists to show that nonproduction workers have become more concentrated in metropolitan areas while production workers have become more concentrated in smaller settlements (Moriarty, 1986). The redistribution of manufacturing has fostered the development of a mosaic of geographically bifurcated labor markets among the larger and smaller urban centers of the country. The trends reveal a growing spatial division of labor in which the Manufacturing Belt and larger cities have spun-off lower income production jobs to other regions and smaller settlements while growing in higher income, external-control functions and higher-value manufacturing. The locational adjustments stem from the ongoing restructuring of the functional operations within manufacturing.

At the same time industrial employment has been decentralizing within the nation, U.S. corporations have been establishing manufacturing facilities abroad. In 1950, total U.S. direct investment in offshore locations amounted to only 3.9 percent ( $\$ 3.8$ billion) of the fixed capital investment in American locations. By 1977, the ratio had reached 9.4 percent ( $\$ 66$ billion), and 1,841 U.S. multinational corporations owned a majority interest in 9,702 offshore affiliates, with almost half owning two or more separate facilities: an average of more than five facilities per corporation (Whichard,
1981; Baker, 1981). Parent firms employed 17.1 million workers overall: 11.8 million in the United States (nearly 60 percent of the nation's manufacturing workers) and 5.3 million abroad, or about one-third of their total workers. The great majority of these workers were employed in production jobs for lower average wages than paid in the United States. Multinational firms accounted for 84 percent of the nation's exports in 1977 but only 77 percent in 1982, as many of the firms moved a greater proportion of their production to more competitive overseas locations (The Economist, 1986). An analysis of the investment data reveals that a direct relationship exists be tween the annual amount of direct investment abroad and the proportion of U.S. total annual fixed capital investment in equipment $\left(r^{2}=\right.$ $.44, N=30$ ). The greater the proportion of U.S. capital investment in equipment, the greater the annual U.S. direct investment abroad.

This is evidence that when manufacturing firms are expending greater proportions of capital on productivity increases rather than on plant capacity increases within the country, they are also heavily investing in offshore facilities. Offshore investment activity declines when firms are expanding domestic plant capacity. While the proportion of total capital invested in productivity increases compared to capacity increases within the country was directly related to real interest rates, the level of capital investment in offshore facilities was a function of both real domestic interest rates and overseas exchange rates on the dollar (Table 2). Depending upon the exchange rate, the greater the U.S. real interest rate, the greater was offshore capital investment $\left(R^{2}=92\right)$. The lower the value of the dollar abroad, the greater was the rate of offshore investment.

In summary, the principal theme of industrial development for several decades now has been its decentralization from and within

Table 2

Regression Analysis of Capital Investment Abroad: 1950-1980

\begin{tabular}{|c|c|c|c|c|c|}
\hline Constant & $\begin{array}{c}\text { Currency Exchange } \\
\text { Rate (U.S.-Swiss) }\end{array}$ & $\begin{array}{l}\text { Real Interest } \\
\text { Rate }\end{array}$ & $\begin{array}{l}\text { Standard } \\
\text { Error }\end{array}$ & $\mathbf{R}^{2}$ & Multiple F \\
\hline $\begin{array}{l}34,211 \\
\text { (millions) }\end{array}$ & $\begin{array}{c}-7.326 \\
(304.336)\end{array}$ & $\begin{array}{c}1.170 \\
(19.000)\end{array}$ & 1.674 & 0.92 & 155.490 \\
\hline
\end{tabular}

Source: Author. The real interest rate and currency exchange rate are lagged, three-year floating averages. The real interest rate is the average six-month treasury bill rate less the consumer price index for the year. F values in parentheses. 
established manufacturing districts to small settlements (and offshore sites) in more peripheral areas. In the past, low wage industry dominated small town locations. More recently, high wage industry has followed suit.

\section{Industrial Restructuring}

While industry has been decentralizing, manufacturing has been undergoing a change from a substantial amount of employment in proprietor-operated, single-plant establishments to manager-operated multiplant firms as the main generators of manufacturing employment. In 1947, multiplant firms accounted for 15 percent of the nation's manufacturing plants and 56 percent of its manufacturing workers. By 1982, multiplant firms controlled only 23 percent of the domestic plants but 75 percent of the jobs. The relatively few multiplant-multinational enterprises are the major generators of manufacturing employment in the country, not the many small, single-plant establishments.

By way of illustration, 410 manufacturing firms comprising the Fortune 500 list owned 14,913 plants in 1978 (Schmenner, 1982, p. 249). This was an average of 36.4 plants each, compared to 31.2 plants in 1972, the addition of approximately one new plant per year for each firm despite a major economic recession during 1975-1976. In 1978, these plants employed $7,346,000$ workers or 37 percent of the manufacturing employment accounted for by the 1977 census of manufacturing: an increase of $1,041,237$ workers over their 1972 total. A number of the new plants were obtained by acquisition and merger as well as by the construction of new facilities. Many of the firms had developed into giant conglomerates in the 1960s, with 1969 the record year for merger activity in the United States. More than 6000 total merger transactions took place in an effort to upgrade efficiency in production and distribution to meet competition in the world market. Merger activity has remained strong in the country since the 1960s (Simic, 1984).

The process by which the geographic redistribution of manufacturing takes place is based upon the ongoing reorganization of firms' functional operations and the restructuring of investment strategies, as whole industrial sectors become more and more dominated by multiplant corporations confronted by stag- nating sales and progressively rising costs. Several formerly secure national oligopolies have especially become threatened by offshore competition. In the past, many firms had benefited from the agglomeration economies of core industrial regions, but faced with productivity constraints at different functional levels, these firms have compensated for the former advantages by relocating certain of their operations to different geographic areas where other marginal cost advantages could be substituted. The principal mechanism underlying the geographic redistribution process can be found in the direct relationships that exist between settlement size, external economies and wage bills for identical jobs regardless of the region in which they are performed. Since wage bills increase almost automatically with the growth of urban centers (and with plant size), the higher wage bills require industry to become more productive in their operations by the adoption of labor-saving process technology or be priced out of the larger urban centers. The tradition of industrial, technological innovation in the United States supports this proposition. Forty percent of manufacturing innovations between 1945 and 1974 were labor saving compared to 13 percent in Europe and 6 percent in Japan (National Science Board, 1981). Industrial restructuring, with its concomitant capital deepening, has as one of its social costs a reduction in U.S. manufacturing employment. In a bygone era dominated by single-plant firms, industry priced out of the larger centers tended to locate in smaller centers in more distant areas. The multiplant enterprises of today practice a similar strategy, but instead, relocate specific operations only through the acquisition of an existing plant by purchase or merger (in some cases), or the establishment of a branch plant (in most cases). The least competitive, labor-intensive operations are located in the smaller towns and rural areas in even more peripheral regions of offshore countries with lower than average wage bills and external economies.

The settlement-size, industrial-sorting process can most readily be linked to the product life-cycle model in which different inputs and scales of production are required during the different stages of new, improved and mature product manufacturing (Moriarty, 1983). As a result of the cost-savings relationship found to exist between settlement size 
and product life-stage, multiplant firms have moved up the learning curve to take advantage of the marginal returns that can be derived from different size urban centers regardless of the life-stage of their products. Typically, the manufacture of a new product is a small-scale operation involving short production runs that are highly dependent upon conventional production techniques using high-cost engineers, technicians and skilled craftsmen normally found in the larger urban centers of established industrial regions where specialized inputs can also be found. Managerial and marketing personnel are readily available to monitor and decide changes in product design to improve market share. Thus, small plants with lower average wage bills than large plants are more marginally cost-effective in larger metropolitan centers with their overall higher labor costs. In the mature product stage, production processes become routinized and labor-skill requirements reduced so that low-cost, lowskilled labor sites with ready access to domestic or foreign markets become important for plant facilities using specialized, mass production techniques. Such facilities require little in the way of specialized services other than low cost land and utilities. Thus, large plants with higher average wage bills than small plants are more marginally cost effective in small settlements (or offshore countries) with their overall lower labor costs.

\section{Industrial Policy}

Given these empirical realities, U.S. industrial policy conceived to provide several billion dollars in direct grants and guaranteed loans through an Industrial Development Bank (IDB) or Reconstruction Finance Corporation (RFC) and additional billions to support applied research and development activities through a National Technology Foundation (NTF), would certainly benefit American corporations and equity investors. But it would have a limited effect on creating a significant number of new jobs for American workers. This is because grants and loans allocated through the IDB or RFC for U.S. projects can be used to "free-up" multinational corporate funds for the expansion or establishment of offshore affiliates. The same can be said for a policy of investment tax credits and accelerated depreciation allowances. New product manufacturing and process technologies developed through grants by the NTF and investment tax credits can just as easily be installed in offshore plants as American plants. Unlike agricultural policy, which can be made locationally specific because of the nature of farming, industrial policy must take into account the more footloose nature of functionally-structured, multiplant, multinational establishments.

The U.S. government for some time has maintained an industrial policy, at least since 1887 when the ICC endorsed a system of regional freight-rate differentials. The various policy programs have had some influence on the redistribution of industry throughout the country but less so than private economic forces which affect the cost and efficiency of production (Moriarty, 1981; Vaughan, 1977). Policy programs that have exerted the greatest influence are those associated with transportation and labor. Those that regulate energy resources, utilities and international trade have had a more limited effect, and tax policy has had the least effect of all. For the most part the programs have only assisted industry in an ongoing regional redistribution to be more accessible to areas of growing output demand or lower-cost factor inputs. In a few cases policies have led to some regions becoming problem areas. ${ }^{1}$

Industrial policy has been poorly designed to influence the economic forces which affect the cost and efficiency of production that would make U.S. locations more attractive for both domestic and foreign direct industrial investment. Certain tax allowances, along with the IDB, RFC and especially the NTF, constitute policy that directly addresses manufacturing cost and efficiency, but they lack sufficient safeguards to protect against an adverse effect on the growth of the nation's manufacturing workforce. Labor-saving process technology designed to improve productivity will result in proportionally fewer workers.

One simple objective of industrial policy should be the creation of jobs for American workers. Job creation in manufacturing depends in large measure on making American products more price competitive in both domestic and offshore markets. This requires programs that address both reductions in factor costs and improvements in market demand. One way of making American products 
more competitive is by reducing federal government borrowing caused by deficit spending. Government borrowing has been estimated at absorbing up to nearly 70 cents of every dollar of new personal savings in 1983 , and an even higher percentage in 1985 . The result is inflated real interest rates and currency exchange rates on the dollar. The high real interest rates delay new investment, causing productivity growth to slacken. This, along with the over-valued dollar, results in many American products not being as competitive in domestic and offshore markets as they would be under more normal rates.

One policy that would effectively reduce factor costs and not adversely affect job creation is a tax provision that would allow for a substantial reduction in the transportation class rates for export commodities. At the same time the policy would increase the American manufacturer's accessibility to offshore markets. Under such a policy, manufacturers would receive a significant tax creditnot a tax deduction-equal to a portion of the total transportation costs associated with their export products, certified as they clear customs. A reduction in the shipping costs of finished products would allow manufacturing production to be less oriented to market locations. The transportation export tax-credit would give several manufacturers a cost advantage by locating plant facilities in the United States rather than close to their offshore markets, stimulate a greater interest in export trade by U.S. manufacturers, and promote higher job creation in domestic manufacturing firms. It may also help stem the disastrous decline of the nation's merchant fleet.

The existing pattern of industrial location in the United States today reflects the effect of differential regional transport rates. Such freight rates existed in the country for rail carriers between 1887-1950 to benefit the Manufacturing Belt. In 1937, it cost 39 percent more per mile on the average to ship commodities in the South than in the Manufacturing Belt, 47 percent more in the West North Central region, 71 percent more in the Pacific and Mountain regions and 75 percent more in the Southwest (75th Congress, 1937). The regional differences in the rates were an important factor in propelling the Northeast and Great Lakes regions to industrial prominence. A further indication of the impact of freight rates on the location of industry was clearly evident in the dominance of the Pittsburgh area as the center of the steel industry and the Detroit area as the center of the automobile industry. The base-point (f.o.b. Pittsburgh) pricing system allowed for massive, internal scale economies and eliminated much of the advantage that steel firms could achieve by locating plants in proximity to distant markets. The base-point system centering on Pittsburgh from 1900-1924 and several other cities from 1924-1948 gave Pittsburgh a locational advantage that led to the concentration of both steel producers and users in the area. The automobile industry instituted the f.o.b. Detroit pricing-system in 1936, leading to the concentration of auto parts and assembly production in the area. The final elimination of the base point and differential rate structures in 1950 along with transportation innovations in the movement of commodities resulted in other U.S. regions becoming more cost competitive with the Manufacturing Belt for the location of industry, thus facilitating its decentralization throughout the country after World War II.

From World War II up to the early 1970s, transport costs in the United States rose at a lower level than labor costs for a number of industries. This caused some industries to search for branch plant locations where labor costs were low enough to more than offset the additional transport costs incurred in less accessible locations. For many industries, the cost of transporting compact, high-value-per-unit-ofweight, finished and semi-finished products tended to be a small proportion of their total cost. An export, transport-cost tax credit is unlikely to affect the location of manufacturing plants in several of these footloose industries. A tax credit is also unlikely to affect offshore plants in countries whose location is virtually required as a condition of market entry. Since the early 1970s, however, freight costs have risen at a rate over twice that of labor costs. Between 1970 and 1980 the Fantas Company found that common-carrier, firstclass LTL rates increased from 3.5 to 11.33 cwt, or 223 percent. Rail rates increased from 1.00 to $3.71 \mathrm{cwt}$ or 271 percent in the eastern territory alone. During the same period labor costs increased by slightly more than 100 percent (Gabe, 1983). Consequently, transportation costs have increased in their importance in 
Regional Industrial Change, Industrial Restructuring, and U.S. Industrial Policy

Table 3

Regression Analysis of U.S. Direct Investment and Employment Abroad in Manufacturing: 1977

\begin{tabular}{|c|c|c|c|c|c|c|}
\hline & Constant & $\begin{array}{l}\text { Adjusted } \\
\text { GNP (\$) }\end{array}$ & $\begin{array}{l}\left(\log _{e}\right) \text { Distance } \\
\text { from U.S. }\end{array}$ & $\begin{array}{l}\text { Standard } \\
\text { Error }\end{array}$ & $\mathbf{R}^{2}$ & $\begin{array}{c}\text { Multiple } \\
\text { F }\end{array}$ \\
\hline $\begin{array}{l}\text { Offshore capital } \\
\text { Investment (millions) }\end{array}$ & 25,380 & $\begin{array}{c}0.007 \\
(11.239)\end{array}$ & $\begin{array}{l}-2,935 \\
(25.302)\end{array}$ & 1,953 & .57 & 15.922 \\
\hline $\begin{array}{l}\text { Offshore } \\
\text { Employment }\end{array}$ & $1,190,534$ & $\begin{array}{c}0.545 \\
(14.386)\end{array}$ & $\begin{array}{r}-140,800 \\
(11.270)\end{array}$ & 140.392 & .44 & 9.490 \\
\hline
\end{tabular}

Source: Author. GNP is adjusted by the percentage of a country's population that is urbanized. $F$ values in parentheses. Distance is measured between capital cities.

plant location decisions. Thus, the transportation tax credit would have its greatest influence on industries that are transportationcost sensitive, particularly those sensitive to market-distribution costs, nearly half of all manufacturing firms (Norcliff, 1975).

Other changes in the transportation rate structure since World War II have resulted in relative reductions in the cost of shipping inputs, less-than-carload lots and short distances compared to shipping outputs, carload lots and long distances (changes in class rates, commodity rates and group rates respectively). The changes caused several industries to become more market oriented over the past three decades (Chinitz, 1960). Faster growing consumer and producer markets outside the Manufacturing Belt, both in the United States and abroad, attracted a greater share of these industries. A preliminary analysis of U.S. direct investment and employment in manufacturing abroad reveals a direct relationship with the effective size of a country's market and an inverse relationship to its distance from the United States (Table 3). An export transport tax credit, in effect, reverses some of the changes that have made industry more market oriented. It provides relative reductions in the cost of shipping outputs compared to shipping inputs and long distances compared to short distances for certain commodities.

Figure 1 illustrates the transport costs required to assemble material inputs and distribute a finished product per unit of output at several alternative domestic and offshore production sites before and after the enactment of a 33 percent export transportation cost tax credit. Entry and exit ports are shown as being the same location, since it is assumed no viable site exists between them-air space or ocean water, for example. Before the enactment of the tax credit (at $t+o$ ) the cost of distributing the finished product at the leastcost, domestic assembly location (e.g., Cincinnati, Ohio) was more than three times as great as the cost of assembling the material inputs at the same location. On the other hand, at the least-cost, overseas distribution location (e.g., Munich, Germany) the cost of assembling the material inputs was more than twice the cost of distributing the finished product from the same location. The transport costs for all alternative sites between the least-cost distribution and assembly sites are also shown, with the intention that the distribution costs per unit of product are greater than the material assembly costs for each unit. Because of this difference in the transport cost structure, total transport costs before the enactment of the export tax credit are higher at sites in the vicinity of the least cost domestic location but lower at sites in the vicinity of the least cost overseas location. The export tax credit is a mechanism to offset the distribution cost structure. This is illustrated in the figure by a 33 percent reduction in the distribution cost at $t+1$ for domestic sites compared to the distribution costs for the same sites at $t+o$. Comparing the total transport costs for domestic sites at $t$ +1 with overseas sites at $t+o$ shows that all domestic sites have lower total transport costs after the enactment of the tax credit. The assembly costs remain the same before and after the enactment of the tax credit, since the credit only applies to distribution costs.

The graphic analysis also takes into consideration the effect of lower labor costs at offshore sites on the location of manufacturing activity. For each alternative location, the figure illustrates the labor cost per unit of product with domestic sites generally having higher costs than overseas sites. Adding the labor costs and total transport costs at each location (for $t+o$ ) illustrates that nearly all offshore 


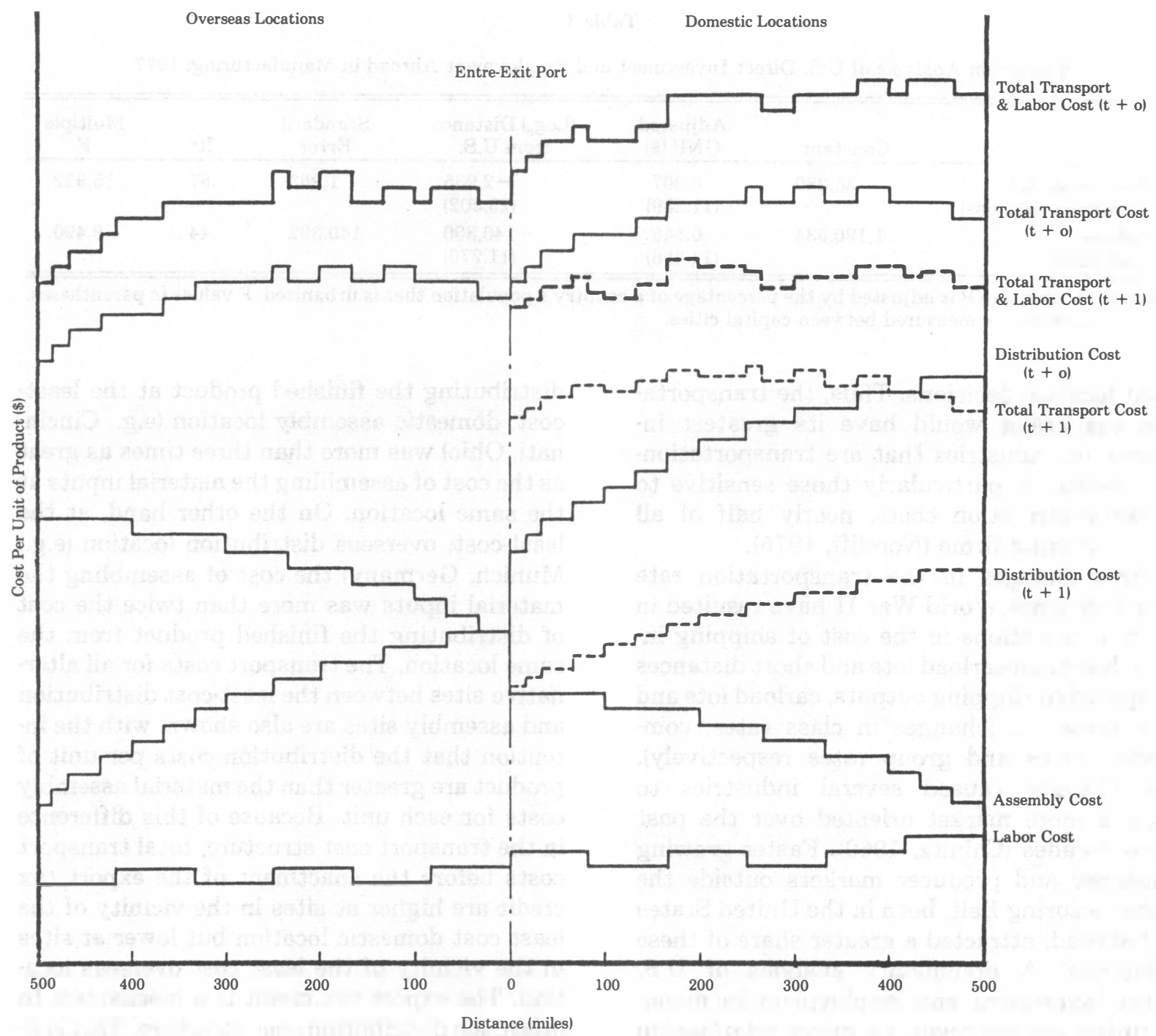

Figure 1

Assembly Costs, Distribution Costs, Total Transport Costs and Labor Costs Per Unit of Product for Manufacturing Locations along a route between Domestic Industries Sites and Overseas Markets before and after an Export Transport Cost Tax Credit.

Note: Labor costs are represented as a differential above a base cost per unit of product.

sites are more cost competitive than the domestic ones. With the enactment of the tax credit, however, the total transport and labor cost (at $t+1$ ) for domestic sites compared to offshore sites (at $t+0$ ) shows all domestic sites to be more cost competitive for the location of production.

\section{Conclusions}

The evidence suggests a new strategy upon which U.S. industrial policy could focus. Consideration should be given to an export transportation cost tax credit as a component of in- dustrial policy, either as federal policy or state policy. A problem appears to exist in that GATT Treaty provisions prohibit tax subsidies to export industries. The tax credit could apply to non GATT countries, but they are not major U.S. trading partners. The GATT provisions, however, apply to price subsidies only and not cost subsidies, such as those incurred in the transportation of goods. The credit, therefore, does not require international agreement as do other GATT codes limiting foreign investment opportunities.

The credit could also be used in conjunction with other development objectives. It could be 
granted to firms meeting certain criteria: 1) locating in prescribed areas such as enterprise zones, freetrade zones or special problem areas such as those with chronic unemployment, or 2) fulfilling specific hiring, training or wage practices. Safeguards would have to be enacted as part of any criteria, such as specifying the level of production that must take place on site to keep the location from being a transshipment point only. And the enactment of the tax credit should depend on whether the revenues derived from corporate and individual income taxes resulting from the direct and indirect increase in domestic manufacturing jobs are great enough to offset the revenues lost through the utilization of the credit.

Based upon such criteria, the tax credit can be considered less of a subsidy to industry than some of the allowances provided under the Economic Recovery Tax Act of 1981, which enabled a number of firms to avoid corporate income taxes. ${ }^{2}$ The Tax Act provided the funds for several corporations to acquire control of other firms, such as General Electric's acquisition of RCA for $\$ 6$ billion with its accumulated tax savings of $\$ 6.5$ billion.

A transportation tax credit tied to development criteria provides a wider range of benefits to the country than the tax laws which were more of a benefit to equity investors. Industrial policy should be designed to serve two client groups: equity investors and American workers. A transportation cost tax credit is a policy that has the potential to fulfill this purpose.

\section{FOOTNOTES}

\footnotetext{
${ }^{1}$ For example, federal (and state) transfer paymentsunemployment insurance, welfare payments (food stamps, housing assistance and medicare), workman's compensation and social security programs-for nonworking individuals and families differ by region of the country, with benefit levels higher in the North than in the South and elsewhere (Moriarty, 1981). Because of the different benefit levels, unskilled and semiskilled labor-force participation rates in areas of the North have declined substantially but have remained high in the South. The North's lower-skilled, lower-wage workers can receive almost as much income from transfer payments (supplemented by occasional unreported day-work) as they can from working (Feldstein, 1976). Since many central city residents tend to be low skilled-the group most likely to substitute welfare income for earned incomeit is not difficult to understand why industry in the North's metropolitan areas has found it increasingly difficult to recruit productive labor, even in areas of high unemployment.
}

${ }^{2}$ The Economic Recovery Tax Act of 1981 provided for reduction in corporate income tax rates, an accelerated cost recovery system, and a 25 percent incremental research and development tax credit. Since 1978, industry has benefited from other federal policies to help improve their competitive position, notably a reduction in capital gains tax rates, real increases in government funding of research and development, increased rationalization of social regulations and reductions in economic regulations.

\section{REFERENCES}

Baker, Betty L. "U.S. Direct Investment Abroad," Survey of Current Business, Oct. 1981.

Bureau of the Census, Census of Manufacturers (Washington, DC: United States Department of Commerce 1954, 1967, 1982).

Bureau of Economic Analyses, U.S. Direct Investment Abroad, 1977 (Washington, DC: United States Department of Commerce, 1981).

Chinitz, Benjamin. "The Effect of Transportation Forms on Regional Economic Growth," Traffic Quarterly, 14 (1960), 129-142.

Cromley, Robert and Thomas R. Leinbach. "The Pattern and Impact of the Filter-Down Process in Nonmetropolitan Kentucky," Economic Geography, 57 (1981), 208-224.

Economist (The). "The World's In-House Traders" (March, 1986), 61.

Erickson, Rodney A. "The Filtering-Down Process: Industrial Location in a Nonmetropolitan Area" Professional Geographer, 28 (1976a); 254-260.

"Nonmetropolitan Industrial Expansion: Emerging Implications for Regional Development," Review of Regional Studies, 6 (1976b), 35-48. and Thomas R. Leinbach. "Characteristics of Branch Plants Attracted to Nonmetropolitan Areas," in Nonmetropolitan Industrialization: eds, R.E. Lonsdale and H.L. Seyler (Washington, DC: V.H. Winston and Sons, 1979) 57-78. and Michael Wasylenko. "Firm Relocation and Site Selection in Suburban Municipalities," Jour nal of Urban Economics, 8 (1980), 69-85.

Feldstein, Martin S. "Temporary Layoffs in the Theory of Unemployment," Journal of Political Economy, 84 (1976), 937-958.

Fuguitt, G.V. and C.L. Beale. "Changes in Population Employment and Industrial Composition in Nonmetropolitan America," Madison, Wisconsin: University of Wisconsin Center for Demography and Ecology (1984).

Gabe, Vernon D. "An Outline of a Corporate Site Location Procedure," Industrial Development, 152 (1983), 23-25.

Hansen, Niles. "The New International Division of Labor and Manufacturing Decentralization in the United States," Review of Regional Studies, 9 (1979), 1-11.

Heaton, T.B. and G.V. Fuguitt. "Nonmetropolitan Industrial Growth and Net Migration," in Nonmetropolitan Industrialization (eds.) R.E. Lonsdale and H.L. Seyler (Washington, DC: V.H. Winston and Sons, 1979), 119-136.

Howell, J.M. "Economic Maturity-Choices and Costs," New York State Senate, ed., Balanced Growth for the Northeast, Albany (1975), 49-76.

Moriarty, Barry M. Industrial Location and Community Development (Chapel Hill, NC: The University of North Carolina Press, 1980).

"Spread and Diffusion Processes in Regional Industrial Employment Growth," in 
Regional Development Under Stagnation, ods. Walter Buhr and Peter Friedrich (Baden-Baden, Germany: Nomos-Verlag: 1981), 149-177.

"Hierarchies of Cities and the Spatial

Filtering of Industrial Development," Papers of the Regional Science Association, 52 (1983), 59-82. "Productivity, Industrial Restructuring and the Deglomeration of American Manufacturing," in Technology, Regions and Policy, ed., John Roes, Totowa, Nj J: Rowman and Littlefield (1986), 141-170.

National Science Board. Science Indicators 1980 (Washington, DC: United States Government Printing Office, 1981).

Norton, R.D. and John Rees. "The Product Cycle and the Spatial Decentralization of American Manufacturing," Regional Studies, 13 (1979) 141-151.

Park, Sam Oak, and James O. Wheeler. "The Filtering Down Process in Georgia: The Third Stage in the Product Life Cycle," Professional Geographer, 35 (1983), 18-31.

Rees, John. "Technological Change and Regional Shifts in American Manufacturing," Professional Geographer, 31 (1979), 45-54.
Schmenner, Roger W. Making Business Location Decisions (Englewood Cliffs, NJ: Prentice-Hall, 1982).

Seventy-fifth Congress, 1st Session, House Document No. 264, The Interterritorial Freight Rate Problem of the United States (Washington, DC: United States House of Representatives, 1937).

Simic, Tomi. Interview (Chicago: W.T. Grimm \& Co., 1984).

Struyk, Raymond J. and Franklin J. James Jr. Intrometropolitan Industrial Location (Lexington, MA: D.C. Heath and Co., 1975).

Till, Thomas. "The Extent of Industrialization in Southern Nonmetro Labor Markets in the 1960s," Joumal of Regional Science, 13 (1973), 453-461.

Vaughan, Roger L. The Urban Impacts of Federal Policy, Vol. 2: Economic Development (RAND Corporation, Santa Monica, 1977).

Whichard, Obie G. "US Direct Investment Abroad," Survey of Current Business, February 1981.

Zelinsky, Wilber. "Has American Industry Been Decentralizing: The Evidence for the 1930-1954 Period," Economic Geography, 38 (1962), 151-189. 